\title{
Evaluation of Sulfentrazone Alone or in Combination with Other PRE and POST Herbicides for Weed Control in Tomato (Solanum lycopersicum) and Strawberry (Fragaria ×ananassa)
}

\author{
Ravneet K. Sandhu, Laura E. Reuss, and Nathan S. Boyd \\ Gulf Coast Research and Education Center, 14625 County Rd 672, \\ Wimauma, FL 33598
}

Additional index words. crop damage, fumigation, herbicide, vegetable weed control, weed competition

\begin{abstract}
Sulfentrazone was recently registered for use in tomato and strawberry in Florida. Field experiments were conducted at the Gulf Coast Research and Education Center in Wimauma, FL, to evaluate PRE sulfentrazone applications when applied on flat soil 30 days before bed formation (PRE-f), on the bed top immediately before laying plastic mulch (PRE-t), applied PRE-t as a tank mix with other PRE herbicides, or PRE-t followed by POST halosulfuron or rimusulfuron (POST). Sulfentrazone did not damage the tomato and strawberry crop and had no effect on strawberry and tomato fruit yield. It was as effective as the industry standards but none of the evaluated herbicide treatments provided adequate weed control. POST halosulfuron in tomato resulted in significantly greater nutsedge control at $11(14 \%)$ and $13(27 \%)$ weeks after initial treatment (WAIT) compared with other treatments in Fall 2019 and Spring 2020, respectively. However, in tomato, tank-mixing sulfentrazone with $S$ metolachlor or metribuzin did not enhance nutsedge control. Weed control did not improve with increased rates or with the use of PRE-f followed by (fb) PRE-t applications in tomato. PRE-t sulfentrazone fb POST halosulfuron was an efficient nutsedge management option in tomato. Sulfentrazone alone did not effectively control weeds in tomato or strawberry. Increased rates of sulfentrazone with the use of PRE-f fb PRE-t sulfentrazone applications did reduce $(34 \%)$ total weed density in strawberry.
\end{abstract}

Florida ranks first and second as a producer of fresh market tomato (Solanum lycopersicum L.) and strawberry (Fragaria $\times$ ananassa) crops with a total economic value of \$426 and \$307 million in 2019 (USDA-NASS, 2020), respectively. Weed control is a major production challenge in Florida, along with other challenges such as high production costs and foreign market competition (Guan et al., 2017; Yu et al., 2020). Yellow (Cyperus esculentus L.) and purple nutsedge (Cyperus rotundus L.) are especially problematic weed species in tomato and strawberry crops (Daugovish and Mochizuki, 2010; Yu et al., 2020). Nutsedge rhizomes grow

Received for publication 23 Sept. 2021. Accepted for publication 27 Oct. 2021.

Published online 10 January 2022

We thank the FMC Corporation, Philadelphia, PA, for providing financial support. We thank the Gowan Corporation, Yuma, AZ, for providing halosulfuron. We also thank the weed science lab team members at the Gulf Coast Research and Education Center, Balm, FL.

R.K.S is a Postdoctoral Associate.

L.E.R. is a Biological Scientist.

N.S.B. is an Associate Professor.

N.S.B. is the corresponding author. E-mail: nsboyd@ ufl.edu.

This is an open access article distributed under the CC BY-NC-ND license (https://creativecommons. org/licenses/by-nc-nd/4.0/). rapidly under the plastic mulch and can produce multiple shoots in a few weeks (Webster, 2005b). Plastic mulches inhibit the emergence of grasses and broadleaf weeds but do not impede nutsedges, as their pointed shoot tips pierce plastic mulches (Gifford and Bayer, 1995; Webster, 2005b).

Several greenhouse studies have reported that nutsedge density, time of emergence, and resource competition affects the yield of tomatoes, bell peppers, and eggplants (MoralesPayan et al., 1997, 2003), whereas field studies conducted in Florida (Boyd, 2015; Boyd and Reed, 2016) reported that nutsedge growing on the bed did not reduce strawberry and tomato yield. Contrastingly, a field study reported a significant decrease in marketable yields of radish due to nutsedge interference in Florida (Santos et al., 1998). Although effects of nutsedge population on vegetable crop yields are inconsistent, uncontrolled populations spread rapidly, reduce crop quality, affect mulch integrity, and increase labor associated with harvest and mulch removal (Adcock et al., 2008; Preece and Read, 2005). Furthermore, the allelopathic effects of nutsedge tubers are known to affect the root and shoot growth of cucumbers and tomato (Alsaadawi and Salih, 2009).

A variety of PRE herbicides (may be applied on flat ground or raised beds before planting the crop) are registered in strawberry and vegetables, but none are effective on nutsedge species, and as a result, growers tend to rely on fumigants for weed control. However, fumigants are found to be more effective for long-term weed control when used in combination with herbicides applied PRE and POST (Yu et al., 2019). Several PRE herbicides, including sulfentrazone, S-metolachlor, and fomesafen, are registered in tomato and are applied on raised beds under the plastic mulch (Boyd et al., 2019; Mohseni-Moghadam and Doohan, 2017; Yu et al., 2020). However, various studies have reported that these chemicals have inconsistent effects on nutsedge control over time (Boyd and Reed, 2016; Johnson and Mullinix, 2005; Yu and Boyd, 2017; Yu et al., 2019).

Previous research has demonstrated that sulfentrazone alone applied on the top of raised beds right before installing plastic (PRE-t) did not effectively control purple nutsedge ( $\mathrm{Yu}$ et al., 2020). Sulfentrazone was newly registered in 2016 for use in tomato and strawberry production in Florida, but how to best integrate sulfentrazone into current weed management programs is still unknown. We hypothesized that pretransplant application of sulfentrazone plus metribuzin on flat ground during fallow period and raised beds before installing plastic mulch fb halosulfuron POST directed basal application could decrease purple nutsedge establishment and provide control throughout the season.

To achieve this goal, we addressed the following objectives: 1) compare two rates of sulfentrazone to control weed populations, 2) compare single bed-top applications vs. a fallow application on flat ground $30 \mathrm{~d}$ before bed formation followed by applications on the bed top to control weeds, and 3) to determine the efficacy of sulfentrazone tank-mixed with other PRE products in controlling weeds in tomato and strawberry.

\section{Materials and Methods}

All the field experiments were conducted at the Gulf Coast Research and Education Center $\left(27^{\circ} \mathrm{N}, 82^{\circ} \mathrm{W}\right)$ in Balm, FL. For both strawberry and tomato experiments, soil type was a Myakka fine sand with a $\mathrm{pH}$ of 7.9, $0.68 \%$ organic matter, and $92.0 \%, 5.2 \%$, and $2.8 \%$ sand, silt, and clay, respectively. The fields used in the studies had a history of purple nutsedge infestation. All experiments were designed as a randomized complete block design with four blocks.

The plot size for all experiments was 7.6 $\mathrm{m}$ of a single raised bed. The tomato beds were spaced $1.22 \mathrm{~m}$ apart and were $0.81 \mathrm{~m}$ at the base, $0.71 \mathrm{~m}$ wide at the top, and $30.5 \mathrm{~cm}$ tall. Tomato beds were formed and fumigated with $118 \mathrm{~kg} \cdot \mathrm{ha}^{-1}$ of $56.6 \%$ Chloropicrin + 37.1\% 1,3-Dichloropropene (Pic-Clor 60 Fumigant; TriEst Ag Group Inc., Greenville, NC) and covered with black and white totally impermeable film (TIF) plastic mulch (1.25 mil) in spring and fall, respectively (Berry Plastic Corp., Evansville, IN). The fumigation was done with a standard fumigation rig equipped 
with three shanks set $20 \mathrm{~cm}$ apart to uniformly distribute fumigant throughout the bed. Two drip tape lines with emitters every $30 \mathrm{~cm}$ and a flow rate of $1.57 \mathrm{~L} \cdot \mathrm{min}^{-1}$ were buried $2.5 \mathrm{~cm}$ beneath the soil surface.

Strawberry beds were fumigated with 136 $\mathrm{kg} \cdot \mathrm{ha}^{-1}$ of $63.4 \%$ 1,3-Dichloropropene + $34.7 \%$ Chloropicrin (Telone C-35 Fumigant, TriEst Ag Group Inc.) and covered with TIF black plastic mulch (Berry Plastic Corp.). The strawberry beds were spaced $1.22 \mathrm{~m}$ apart and were $0.71 \mathrm{~m}$ at the base, $0.66 \mathrm{~m}$ wide at the top, and $30.5 \mathrm{~cm}$ tall, then a single drip tape with emitters every $30 \mathrm{~cm}$ and a flow rate of $1.57 \mathrm{~L} \cdot \mathrm{min}^{-1}$ was placed at the center of the bed just beneath the soil surface. The fumigation was done with a standard fumigation rig (Kennco Manufacturing, Ruskin, FL) equipped with two shanks set $28 \mathrm{~cm}$ apart to uniformly distribute fumigant throughout the bed. The irrigation, fertilization, and management for foliar insect-pests and diseases of tomatoes and strawberries followed industry recommendations.

The PRE-f herbicide sprays were applied using four 8002 EVS nozzles boom at 240 $\mathrm{kPa}$ and spray volume of $189.2 \mathrm{~L} \cdot \mathrm{ha}^{-1}$. All PRE-t herbicide applications were made with a $\mathrm{CO}_{2}$ pressurized backpack sprayer (Bellspray Inc., Opelousa, LA) equipped with a single 8002 EVS nozzle (Teejet Technologies, Wheaton, IL) at a pressure of $240 \mathrm{kPa}$. POST sprays were done with the same nozzles as PRE-t but were directed at the base of the plant on both sides of the bed.

\section{Sequential sulfentrazone applications in tomato}

Experiments were conducted in Spring 2018 and repeated in Fall 2018 to evaluate single bed-top (PRE-t) application of sulfentrazone, sulfentrazone broadcast-applied $30 \mathrm{~d}$ before bed formation (PRE-f) followed by PRE-t applications, and PRE-t fb POST rimsulfuron and halosulfuron. It is important to note that Florida weather does not vary much across fall and spring, which is why experiments were repeated in spring. Herbicides used in treatments (Table 1) were sulfentrazone (Spartan FL 4 F; FMC Corp., Philadelphia, PA), S-metolachlor (Dual II Magnum; Syngenta Crop Protection, LLC, Greensboro, NC), rimsulfuron PRE-t fb $17.7 \mathrm{~g} \cdot \mathrm{ha}^{-1}$ a.i. rimsulfuron POST (Solida Herbicide, FMC Corp.), metribuzin BT (Metribuzin 75DF Herbicide; Makhteshim Agan of North America, Inc., Raleigh, NC), and halosulfuron POST (Sandea Herbicide, Yuman, AZ). The treatments of PRE-f, PRE-t, and POST were made on 29 Jan., 7 Feb., and 2 Apr. 2018, respectively, for the spring experiment, and 25 June, 24 July, and 5 Sept. 2018, respectively, for the fall experiment. Beds were fumigated on $7 \mathrm{Feb}$. 2018, and 6-weekold tomatoes (cv. Charger) seedlings were hand transplanted at $60-\mathrm{cm}$ spacing between plants in the center of the bed on 7 Mar. 2018 , for the spring experiment, and for fall experiment, fumigation was done on 24 July
Table 1. Treatment list of herbicides used in tomato experiment conducted at the Gulf Coast Research and Education Center, Balm, FL, in 2018.

\begin{tabular}{lc}
\hline Herbicide & ${\text { Rate }\left(\mathrm{g} \cdot \mathrm{ha}^{-1} \mathrm{a} . \mathrm{i} .\right)}$ \\
\hline Nontreated control & - \\
Sulfentrazone PRE-f fb sulfentrazone PRE- $\mathrm{t}^{\mathrm{y}}$ & $141.7 \mathrm{fb} 106$ \\
Sulfentrazone PRE-f fb sulfentrazone PRE-t & $212 \mathrm{fb} 212$ \\
Sulfentrazone PRE-t + S-metolachlor PRE-t & $106+1436.5$ \\
Sulfentrazone PRE-t fb rimsulfuron POST & $+106 \mathrm{fb} 17.7$ \\
Sulfentrazone PRE-f + rimsulfuron PRE-f fb rimsulfuron POST & $212+35.4 \mathrm{fb} 17.7$ \\
Metribuzin PRE-t fb halosulfuron POST & $19.8 \mathrm{fb} 53.15$ \\
S-metolachlor PRE-t fb halosulfuron POST & $1436.5 \mathrm{fb} 53.15$ \\
\hline
\end{tabular}

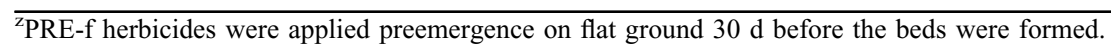

${ }^{y}$ PRE-t herbicides were applied preemergence on the bed top immediately before laying the plastic mulch.

${ }^{\mathrm{x}}$ POST $=$ apply as postemergence herbicide once nutsedge emerges.

$\mathrm{fb}=$ followed by.
2018 and tomato seedlings were transplanted on 15 Aug. 2018.

\section{Data collection}

Total number of purple nutsedge shoots puncturing through the TIF mulch were counted inside the planted area (7.6-m bed) on 2 and 23 Apr. 2018 for the spring experiment, and 27 Sept. and 13 Nov. 2018, for the fall experiment. Tomato injury was visually assessed (where 0 is no injury and 100 denotes complete desiccation) assessed on 21 Mar., 28 Mar., 2 Apr., 16 Apr., and 23 Apr. 2018 in the spring, and on 11 and 27 Sept. 2018 in the fall. Tomato plant height (from base of plant to the top of growth point) was recorded on 21 and 28 Mar. 2018 for the spring experiment, and on 11 and 27 Sept. 2018 for the fall experiment, to quantify herbicide injury and effect on plant growth. Fruit from five tomato plants from each plot were hand-picked on 7 June 2018 for the spring experiment, and 6 and 13 Nov. 2018 for the fall experiment. Tomato fruits were harvested and graded as small $(<58 \mathrm{~mm})$, medium (58-64 mm), large $(64-73 \mathrm{~mm})$, and extra large $(73-88 \mathrm{~mm})$ based on the fruit size (Sandhu et al., 2021).

\section{Sulfentrazone tank mixes in tomato}

Field experiments were conducted in Fall 2019 and Spring 2020. Multiple herbicide combinations applied included 1) preemergence herbicides applied to the bed-top immediately before laying the plastic mulch (PRE-t), and 2) postemergence herbicides applied POST directed to the base of the crop following nutsedge emergence. Herbicide treatments are listed in Table 2. PRE and POST treatments were made on 24 July (initial treatment) and 30 Sept. 2019, respectively, for the fall experiment and on 16 Jan. and 27 Feb. 2020, respectively, for the spring experiment.

Beds were fumigated on 24 July 2019, for the fall experiment, and 16 Jan. 2020 for the spring experiment. Tomatoes (cv. Charger in 2019 and HM1823 in 2020) were transplanted in the center of the bed with $60-\mathrm{cm}$ spacing between plants on 22 Aug. 2019 for the fall experiment, and $45 \mathrm{~cm}$ spacing between plants on 27 Feb. 2020 for the spring experiment. Plot length per treatment was $7.2 \mathrm{~m}$.

\section{Data collection}

The total number of purple nutsedge shoots that pierced the TIF mulch were counted within the plot (planted area) on 22 Aug., 9 Oct., and 14 Nov. 2019, for the first experiment and 20 Feb. and 7 May 2020, for the second. Purple nutsedge injury was visually accessed (where 0 is no injury and 100 is complete desiccation) on 14 Oct. and 21 Oct. 2019 for the first experiment, and 22 Apr., 30 Apr., and 9 May 2020 for the second. Tomato injury (where 0 is no injury and 100 is complete desiccation) was visually accessed on 13 Sept. and 18 Sept. 2019 for the first experiment, and 17 Mar. 2020 for the second. Plot soil moisture readings were recorded on 18
Table 2. Treatment list of herbicides used in tomato experiment conducted at the Gulf Coast Research and Education Center, Balm, FL, in 2019 and 2020.

\begin{tabular}{lc}
\hline Treatment & ${\text { Rate }\left(\mathrm{g} \cdot \mathrm{ha}^{-1} \text { a.i. }\right)}^{\text {Nontreated }}$ \\
Sulfentrazone PRE- $\mathrm{t}^{\mathrm{z}}$ & - \\
Sulfentrazone PRE-t & 106 \\
Sulfentrazone PRE-t fb halosulfuron POST & 212 \\
Sulfentrazone PRE-t fb halosulfuron POST & $106 \mathrm{fb} 53.2$ \\
Sulfentrazone + S-metolachlor PRE-t & $212 \mathrm{fb} 53.2$ \\
Sulfentrazone + S-metolachlor PRE-t & $106+864$ \\
Sulfentrazone + metribuzin PRE-t & $212 \mathrm{fb} 864$ \\
Sulfentrazone + metribuzin PRE-t & $106+561.8$ \\
Metribuzin PRE-t fb halosulfuron POST & $212+561.8$ \\
\hline
\end{tabular}

${ }^{\mathrm{z}}$ PRE-t herbicides were applied preemergence on the bed top immediately before laying the plastic mulch.

${ }^{\mathrm{y}} \mathrm{POST}$ post transplanting (to the base of plant) applied at 9 week after PRE-t.

$\mathrm{fb}=$ followed by. 
July 2019 for the first experiment, and 16 Jan. 2020 for the second. Broadleaf weeds and grasses growing in the planting holes were counted on 15 Nov. 2019 for the first experiment and 7 May 2020 for the second. Fruits from five tomato plants were handpicked from each plot on 7 and 20 Nov. 2019 for the first experiment, and 27 May 2020 for the second. Tomato fruits were harvested and graded as small $(<58 \mathrm{~mm})$, medium $(58-64$ $\mathrm{mm})$, large $(64-73 \mathrm{~mm})$, and extra large (73-88 mm) based on the fruit size (Sandhu et al., 2021).

\section{Sulfentrazone in strawberry}

Two spatially separated runs (1 and 2) of the experiment were conducted in Fall 2018 to evaluate sulfentrazone for weed control in strawberry. Beds were fumigated on 16 Aug. 2018 for experimental run 1, and 5 Oct. 2018 for experimental run 2. Herbicide treatments (Table 3) were sulfentrazone, napropamide (Devrinol 2-XT; Northwest Crop Protection, LLC, Bonners Ferry, ID), and flumioxazin (Chateau Nufarm, Otahuhu, Auckland, New Zealand). Two parallel rows of strawberry plants (cv. Radiance) were transplanted per bed with $38-\mathrm{cm}$ plant-plant spacing on 11 Oct. 2018 for experimental run 1, and 25 Oct. 2018 for experimental run 2 .

\section{Data collection}

The number of purple nutsedge shoots, broadleaf weeds, and grasses were counted within the planted area on 21 Nov. 2018, and 4 Jan., 15 Jan., and 10 Feb. 2019 in experimental run 1, and on 5 Oct., 9 Nov., 15 Nov., and 21 Nov. 2018, and 4 Jan., 17 Jan., and 20 Feb. 2019 in experimental run 2. Strawberry injury and weed control (where 0 is no injury and 100 represents complete desiccation) were visually evaluated in experimental run 1 on 21 Nov., and in experimental run 2 on 5 Nov., 9 Nov., 15 Nov., 21 Nov., and 6 Dec. 2018. Strawberry shoot biomass was collected from four randomly selected strawberry plants on 19 Mar. in both experimental runs. Weed biomass per meter per plot was collected on the same day. Approximately 30 strawberry plants per plot were harvested (only marketable fruit) twice a week from all plots from early Jan. to 14 Feb. 2019. All fruit per plot were weighed for overall yield.

\section{Data analysis}

Data were analyzed using the Proc Mixed procedure in SAS (version 9.4; SAS Institute, Cary, NC). Block was considered a random variable and herbicide treatments a fixed variable. Experimental runs were analyzed separately as data collection occurred on different dates. Data assumptions were checked for normality and constant variance before analysis. Treatment means were separated using the least squares means statement in SAS with the post hoc Tukey adjustment at $P=$ 0.05 .
Table 3. Treatment list of herbicides used in strawberry experiment conducted at the Gulf Coast Research and Education Center, Balm, FL, in 2019 and 2020.

\begin{tabular}{lc}
\hline Herbicide treatment & Rate $\left(\mathrm{g} \cdot \mathrm{ha}^{-1}\right.$ a.i. $)$ \\
\hline Nontreated control & - \\
PRE-t ${ }^{\mathrm{z}}$ sulfentrazone & 106 \\
PRE-f sulfentrazone fb PRE-t sulfentrazone & $106 \mathrm{fb} 106$ \\
PRE-f sulfentrazone fb PRE-t sulfentrazone & $141.7 \mathrm{fb} 141.7$ \\
PRE-f sulfentrazone fb PRE-t sulfentrazone & $212 \mathrm{fb} 212$ \\
PRE-t sulfentrazone + PRE-t napropamide & $106+2267.5$ \\
PRE-t flumioxazin & 107
\end{tabular}

${ }^{\mathrm{Z}}$ PRE-t herbicides were applied preemergence on the bed top immediately before laying the plastic mulch.

${ }^{\mathrm{y}}$ PRE-f herbicides were applied preemergence on flat ground $30 \mathrm{~d}$ before the beds were formed. $\mathrm{fb}=$ followed by.

\section{Results and Discussion}

\section{Sequential sulfentrazone applications in tomato}

Season by treatment interaction was significant $(P<0.001)$, so the results of two seasons are presented separately. No significant control was observed on nutsedge $(P$ $=0.294)$ in the spring experiment throughout the season. In the fall, all herbicide treatments caused minimal visual nutsedge damage $(\leq 8 \%)$ on 11 Sept. 2018 [4 weeks after transplanting (WAT)] (Table 4). Smetolachlor PRE-t fb halosulfuron POST and metribuzin PRE-t $\mathrm{fb}$ halosulfuron POST caused $29 \%$ and $55 \%$ nutsedge damage $(P<$ 0.001 ) on 27 Sept. 2018 (7 WAT), respectively, whereas the other herbicide treatments caused $\leq 10 \%$ visual nutsedge damage.
Table 4. Nutsedge control following the herbicide treatments in the tomato experiment conducted at the Gulf Coast Research and Education Center in Balm, FL, in Fall 2018.

\begin{tabular}{|c|c|c|c|c|c|c|}
\hline \multirow[b]{3}{*}{ Herbicide } & \multirow{3}{*}{$\begin{array}{c}\text { Rate } \\
\left(\mathrm{g} \cdot \mathrm{ha}^{-1} \text { a.i. }\right)\end{array}$} & \multicolumn{2}{|c|}{ Nutsedge damage } & \multicolumn{3}{|c|}{ Nutsedge density } \\
\hline & & $\begin{array}{c}11 \text { Sept. } \\
2018\end{array}$ & $\begin{array}{c}27 \text { Sept. } \\
2018\end{array}$ & $\begin{array}{l}16 \text { Aug. } \\
2018\end{array}$ & $\begin{array}{l}27 \text { Sept. } \\
2018\end{array}$ & $\begin{array}{c}13 \text { Nov. } \\
2018\end{array}$ \\
\hline & & \multicolumn{2}{|c|}{$\%$} & \multicolumn{3}{|c|}{ shoots $/ \mathrm{m}^{2}$} \\
\hline $\begin{array}{l}\text { Nontreated } \\
\text { control }\end{array}$ & - & 0 & $0 \mathrm{~b}^{\mathrm{z}}$ & 13.1 & $22.4 \mathrm{ab}$ & $20.2 \mathrm{ab}$ \\
\hline $\begin{array}{l}\text { Sulfentrazone } \\
\text { PRE- } \mathrm{f}^{\mathrm{y}} \mathrm{fb} \\
\text { sulfentrazone } \\
\text { PRE- } \mathrm{t}^{\mathrm{x}}\end{array}$ & $141.7 \mathrm{fb} 106$ & 0 & $8 \mathrm{~b}$ & 12.9 & $26.6 \mathrm{a}$ & $27.4 \mathrm{a}$ \\
\hline $\begin{array}{l}\text { Sulfentrazone } \\
\text { PRE-f fb } \\
\text { sulfentrazone } \\
\text { PRE-t }\end{array}$ & $212 \mathrm{fb} 212$ & 3 & $4 \mathrm{~b}$ & 8.1 & $15.8 \mathrm{ab}$ & $22.9 \mathrm{ab}$ \\
\hline $\begin{array}{l}\text { Sulfentrazone } \\
\text { PRE-t + S- } \\
\text { metolachlor } \\
\text { PRE-t }\end{array}$ & $\begin{array}{l}106+ \\
1436.5\end{array}$ & 0 & $3 \mathrm{~b}$ & 11.1 & $20.8 \mathrm{ab}$ & $21.9 \mathrm{ab}$ \\
\hline $\begin{array}{l}\text { Sulfentrazone } \\
\text { PRE-t fb } \\
\text { rimsulfuron } \\
\text { POST }\end{array}$ & $106 \mathrm{fb} 17.7$ & 5 & $3 \mathrm{~b}$ & 12.5 & $25.3 \mathrm{a}$ & $28.3 \mathrm{a}$ \\
\hline $\begin{array}{l}\text { Sulfentrazone } \\
\text { PRE-f + } \\
\text { rimsulfuron } \\
\text { PRE-f fb } \\
\text { rimsulfuron } \\
\text { POST }^{\mathrm{w}}\end{array}$ & $\begin{array}{c}212+35.4 \\
\text { fb } 17.7\end{array}$ & 3 & $10 \mathrm{~b}$ & 11 & $21.3 \mathrm{ab}$ & $18.9 \mathrm{ab}$ \\
\hline $\begin{array}{l}\text { Metribuzin PRE- } \\
\mathrm{t} \mathrm{fb} \\
\text { halosulfuron } \\
\text { POST }\end{array}$ & $19.8 \mathrm{fb} 53.15$ & 8 & $55 \mathrm{a}$ & 9.4 & $6.5 \mathrm{~b}$ & $8.4 \mathrm{~b}$ \\
\hline $\begin{array}{l}S \text {-metolachlor } \\
\text { PRE-t fb } \\
\text { Halosulfuron } \\
\text { POST }\end{array}$ & $\begin{array}{c}1436.5 \mathrm{fb} \\
53.15\end{array}$ & 8 & $29 \mathrm{ab}$ & 11.7 & $11.4 \mathrm{ab}$ & $13.8 \mathrm{ab}$ \\
\hline$P$ value & & 0.0517 & $<0.0001$ & 0.6842 & 0.0087 & 0.3087 \\
\hline
\end{tabular}

$\overline{\mathrm{z}}$ Different letters within a column indicate a significant difference $(\alpha=0.05)$ by Tukey's honestly significant difference.

${ }^{y}$ PRE-f herbicides were applied preemergence on flat ground $30 \mathrm{~d}$ before the beds were formed. ${ }^{x}$ PRE-t herbicides were applied preemergence on the bed top immediately before laying the plastic mulch. ${ }^{\mathrm{w}} \mathrm{POST}=$ apply as postemergence herbicide once nutsedge emerges. $\mathrm{fb}=$ followed by. 
POST halosulfuron did not control nutsedge but generally increased nutsedge damage.

Only metribuzin PRE-t fb POST halosulfuron treatment resulted in significant nutsedge control compared with nontreated control. Post emergence halosulfuron suppressed nutsedge, whereas other authors reported control (Adcock et al., 2008; Gricher et al., 2003; Shaner, 2014). None of the herbicide combinations significantly reduced nutsedge density in comparison with the nontreated control in the spring experiment (Table 4). In the fall, metribuzin PRE-t fb halosulfuron POST significantly $(P=0.008)$ lowered nutsedge density compared with treatment that included two successive applications of sulfentrazone on 27 Sept. 2018. Neither one of the herbicide treatments significantly reduced broadleaf and grass weed density in the planting holes.

Previous authors have noted that POST emergence applications of halosulfuron can effectively control nutsedge, and many common broadleaf weeds found in Florida tomato fields, including eclipta, common purslane, hairy indigo, and pigweed (Shrefler et al., 2007; Webster, 2010; Yu et al., 2018). The lack of efficacy noted in our trials may have been because some of the nutsedge were starting to flower when POST herbicides were applied. This indicates that there is more research needed to explore the herbicide application timing to efficiently manage nutsedge.

Tomato damage, yield, and growth. The herbicide treatments did not significantly injure tomato plants. No differences were observed in tomato plant heights and damage among herbicide treatments in both spring and fall experiments. None of the herbicide treatments varied significantly from the nontreated control in terms of tomato fruit yield in the different grading categories in either spring or fall experiments. Sulfentrazone is registered for tomato, and recommended rates of other POST herbicides were used, so no tomato damage was observed (Sandea herbicide, 2015; Spartan 4F herbicide, 2014). Previous studies reported on sulfentrazone and halosulfuron have shown similar results (Boyd, 2015; Yu et al., 2020). Overall results from the experiment indicate that sequential applications of sulfentrazone $30 \mathrm{~d}$ apart did not improve nutsedge control and caused no tomato damage, and as a result this practice is not recommended.

\section{Sulfentrazone tank mixes in tomato}

PRE-t sulfentrazone alone or tank-mixed with S-metachlor did not effectively control overall weed population including nutsedge and broadleaf weeds (Table 5). The results of the current study are in agreement with previous research where inconsistent and unreliable control of nutsedge has been reported with sulfentrazone treatments (Boyd, 2015; Gricher et al., 2003; Yu and Boyd, 2017). Sulfentrazone PRE-t mixed with S-metachlor/metribuzin and sulfentrazone fb halosulfuron had significantly $(P=0.008)$ lower nutsedge densities compared with the nontreated control on 28 Oct. 2019 (13 WAITweeks after initial treatment) in the fall experiment. However, there was no effect of herbicide treatments on nutsedge density in the spring experiment.

Nutsedge damage was significantly $(P=$ 0.025 and $<0.001$, respectively) higher in sulfentrazone $\mathrm{fb}$ halosulfuron treatments on 21 Oct. 2019 (11 WAIT) and 22 Apr. 2020 (14 WAIT) compared with other treatments in the fall and spring experiments, respectively (Table 5). Sulfentrazone at 106 and $212 \mathrm{~g} \cdot \mathrm{ha}^{-1}$ a.i. fb halosulfuron at $53.2 \mathrm{~g} \cdot \mathrm{ha}^{-1}$ a.i. (POST) caused $26 \%$ to $29 \%$ nutsedge damage, respectively, at 14 WAIT in the spring experiment. This damage was largely due to POST halosulfuron. PRE-t sulfentrazone tank mixes tended to be as effective as PRE-t sulfentrazone $\mathrm{fb}$ POST halosulfuron initially, but populations tended to recover. Given the lack of control in the spring experiment, we concluded that all treatments evaluated provided inconsistent suppression.

Tomato damage and yield. None of the herbicide treatments significantly injured tomato plants (Table 6). Tomato damage ranged from $2 \%$ to $6 \%$ in 2019 and no damage was observed in 2020. Plots with sulfentrazone (PRE-t) and sulfentrazone + metribuzin (PRE-t) had higher total tomato yields compared with the nontreated control in 2019. This effect could have been due to reduced competition because of low nutsedge population in the herbicide treatments. No herbicide treatments reduced tomato yields in 2020 (Table 6); however, the tomato yields were consistently lower in Fall 2019 in all treatments compared with Spring 2020 because of bacterial wilt incidence. We conclude that tank-mixing sulfentrazone with S-metolachlor or metribuzin did not enhance nutsedge control.

\section{Sulfentrazone in strawberry}

In experimental run 1 , no broadleaf and grass weeds emerged by 21 Nov., and there was no control of purple nutsedge by any of the herbicide treatments. In experimental run

Table 5. Purple nutsedge damage and counts after herbicide treatments in plasticulture tomato in Balm, FL, in 2019 and 2020.

\begin{tabular}{|c|c|c|c|c|c|c|c|c|c|c|c|}
\hline \multirow[b]{3}{*}{ Treatment } & \multirow[b]{3}{*}{ Rate $\left(g \cdot h a^{-1}\right.$ a.i.) } & \multicolumn{4}{|c|}{ Nutsedge damage } & \multicolumn{6}{|c|}{ Nutsedge count } \\
\hline & & 14 Oct. & 21 Oct. & 22 Apr. & 30 Apr. & 22 Aug. & 9 Oct. & 28 Oct. & 14 Nov. & $20 \mathrm{Feb}$. & 7 May \\
\hline & & \multicolumn{4}{|c|}{$\%$} & \multicolumn{6}{|c|}{ no. of shoots $/ \mathrm{m}^{2}$} \\
\hline Nontreated & - & 0 & 0 & 0 & 0 & 21 & 90 & $78 \mathrm{a}^{\mathrm{z}}$ & 76 & 271 & 49 \\
\hline Sulfentrazone PRE-t & 106 & 5 & 2.5 & 0 & 0 & 10 & 31 & $41 \mathrm{ab}$ & 63 & 244 & 46 \\
\hline Sulfentrazone PRE-t & 212 & 0 & 7.5 & 0 & 0 & 5 & 35 & $29 a b$ & 40 & 295 & 65 \\
\hline $\begin{array}{l}\text { Sulfentrazone PRE-t } \\
\text { fb halosulfuron } \\
\text { POST }\end{array}$ & $212 \mathrm{fb} 53.2$ & 2.5 & 15 & 28.7 & 0 & 9 & 53 & $14 \mathrm{~b}$ & 28 & 253 & 43 \\
\hline $\begin{array}{l}\text { Sulfentrazone }+ \text { S- } \\
\text { metolachlor PRE-t }\end{array}$ & $106+864$ & 5 & 0 & 0 & 0 & 11 & 46 & $52 \mathrm{ab}$ & 58 & 329 & 40 \\
\hline $\begin{array}{l}\text { Metribuzin PRE-t fb } \\
\text { halosulfuron } \\
\text { POST }\end{array}$ & $561.8 \mathrm{fb} 53.2$ & 7.5 & 10 & 25 & 0 & 10 & 44 & $18 \mathrm{~b}$ & 30 & 330 & 46 \\
\hline$P$ value & & 0.2259 & 0.0259 & $<0.0001$ & - & 0.2698 & 0.182 & 0.008 & 0.076 & 0.946 & 0.703 \\
\hline
\end{tabular}

${ }^{\mathrm{z}}$ Different letters within a column indicate a significant difference $(\alpha=0.05)$ by Tukey's honestly significant difference.

${ }^{\mathrm{y}} \mathrm{POST}$ applied at 9 weeks after PRE-t.

$\mathrm{fb}=$ followed by; POST = POSTransplanting (to the base of plant); PRE-t $=$ on the bed right before laying plastic. 


\begin{tabular}{|c|c|c|c|c|c|}
\hline \multirow[b]{3}{*}{ Treatment } & \multirow[b]{3}{*}{ Rate (g.ha ${ }^{-1}$ a.i. $)$} & \multicolumn{2}{|c|}{ Tomato damage } & \multicolumn{2}{|c|}{ Tomato yield ${ }^{z}$} \\
\hline & & Fall 2019 & Spring 2020 & Fall 2019 & Spring 2020 \\
\hline & & \multicolumn{2}{|c|}{$\%$} & \multicolumn{2}{|c|}{$\mathrm{kg} \cdot \mathrm{ha}^{-1}$} \\
\hline Nontreated & - & 0 & 0 & $1,199.7 b^{y}$ & 64,910 \\
\hline Sulfentrazone PRE-t & 106 & 0 & 0 & $23,232 \mathrm{ab}$ & 55,883 \\
\hline Sulfentrazone PRE-t & 212 & 1.25 & 0 & $27,281 \mathrm{a}$ & 52,945 \\
\hline Sulfentrazone PRE-t fb halosulfuron POST & $106 \mathrm{fb} 53.2$ & 5 & 0 & $17,384 \mathrm{ab}$ & 50,724 \\
\hline Sulfentrazone PRE-t fb halosulfuron POST & $212 \mathrm{fb} 53.2$ & 5 & 0 & $10,414 \mathrm{ab}$ & 59,393 \\
\hline Sulfentrazone + S-metolachlor PRE-t & $106+864$ & 0 & 0 & $21,749 \mathrm{ab}$ & 65,268 \\
\hline Sulfentrazone + S-metolachlor PRE-t & $212 \mathrm{fb} 864$ & 0 & 0 & $19,169 \mathrm{ab}$ & 50,796 \\
\hline Sulfentrazone + metribuzin PRE-t & $106+561.8$ & 3.75 & 0 & $16,012 \mathrm{ab}$ & 61,041 \\
\hline Sulfentrazone + metribuzin PRE- $t$ & $212+561.8$ & 0 & 0 & $32,588 \mathrm{a}$ & 46,784 \\
\hline Metribuzin PRE-t fb halosulfuron POST & $561.8 \mathrm{fb} 53.2$ & 2.5 & 0 & $22,506 \mathrm{ab}$ & 51,083 \\
\hline$P$ value & & 0.712 & - & 0.012 & 0.877 \\
\hline
\end{tabular}

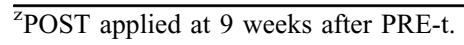

${ }^{\mathrm{y}}$ Different letters within a column indicate a significant difference $(\alpha=0.05)$ by Tukey's honestly significant difference.

$\mathrm{fb}=$ followed by; POST $=$ POSTransplanting (to the base of plant); PRE- $\mathrm{t}=$ on the bed right before laying plastic.

2 , weed damage ratings were taken on more dates than experimental run 1 , but no differences were observed between treatments $(P=0.803)$.

In experimental run 1 , total weed density (broadleaf, nutsedge, and grass weeds) varied with herbicide $(<0.001)$ and time $(<0.001)$, but the effects of herbicide treatment did not vary with time $(P=0.544)$, consequently weed density is presented as averaged over time (Table 7). A similar trend was observed for experimental run 2 , where total weed density varied with herbicide $(P=0.003)$ and time $(<0.001)$, but the effects of herbicide treatment did not vary with time $(P=0.799)$. Averaged across herbicide treatments, total weed density in experimental run 1 increased from 3 weeds $/ \mathrm{m}^{2}$ on 21 Nov. to a peak of 14 weeds $/ \mathrm{m}^{2}$ on 4 Jan. No differences were observed in weed density in plots treated with sulfentrazone PRE- $t$ + napropamide PRE- $t$ compared with control. However, previous study reported $41 \%$ reduction in nutsedge emergence with napropamide application through drip (Yu and Boyd, 2017). In experimental run 2, weed density peaked at 30 weeds $/ \mathrm{m}^{2}$ on Nov. 2 and declined thereafter. The weed density tended to be lower in all herbicide treatments in comparison with the nontreated control (Table 7). The sulfentrazone efficacy did not vary with rate or application timing, and all sulfentrazone treatments except the highest rate of PRE-f fb PRE-t sulfentrazone were as effective as the industry standard in both experimental runs.

Lower residual persistence of these herbicides applied PRE-t in soil could result in poor weed control in late season ( $\mathrm{Yu}$ et al, 2019). Thus, increased weed density later in the season make it an unreliable practice to control nutsedge, especially in strawberries. However, the higher concentration of sulfentrazone applied on bed top and before plastic installation provided better overall weed control in strawberries.

Crop damage and yield. None of the herbicide treatments damaged the crop in either experimental run. Herbicide treatment had no effect on the number of strawberry transplants that died or the shoot biomass in either of experimental runs (Table 8). Plant survival in experimental run 2 was much lower than run 1 due to severe disease pressure. No differences were observed in strawberry yields between herbicide treatments but PRE-t flumioxazin tended to yield more fruit.
Nutsedge that appears late in the season is very crucial because the nutsedge tubers could stay in the soil for numerous successive seasons and reproduce rapidly (Neeser et al., 1997; Webster, 2005a, 2005b). Moreover, weeds reduce plastic stability, hinder harvesting, alternate hosts for insects-pests, and hinder plastic removal, which ultimately increase the management costs. Thus, halosulfuron POST application is needed to control nutsedge later in the season and reduce tuber production in tomato crop because of minimal effect of PRE-t herbicides on weed control (Bangarwa et al., 2009; Boyd, 2015; Gricher et al., 2003; Miller and Dittmar, 2014; Webster and Grey, 2014).

On the contrary, there are no previous studies reported on effect of sulfentrazone applied in strawberries in Florida. Figueroa et al. (2005) reported that sulfentrazone had no effect on plant stunting, leaf injury, and strawberry yield in Ohio. Future studies are required to determine the effects and safety of other post emergence herbicides in tomato and strawberries.

Sulfentrazone did not damage tomato and strawberry crop or affect yield. It was as effective as the industry standards, but

Table 7. The effects of herbicide treatments on the total weed density and biomass in strawberry at the Gulf Coast Research and Education Center in Balm, FL, in 2018.

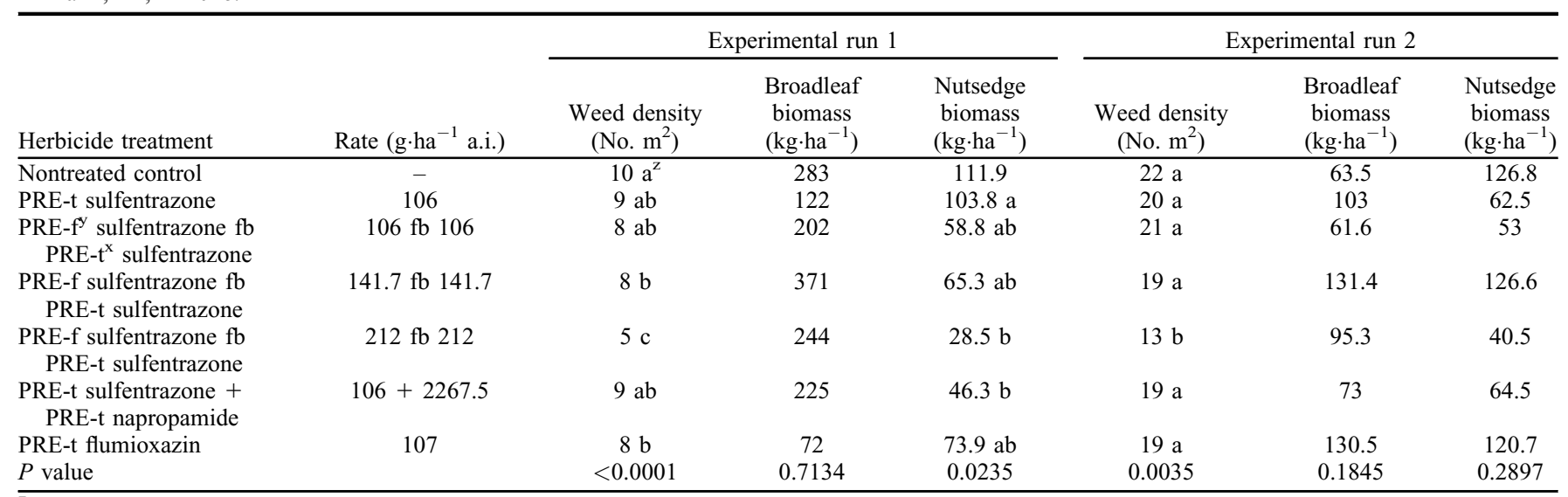

${ }^{\mathrm{z}}$ Different letters within a column indicate a significant difference $(\alpha=0.05)$ by Tukey's honestly significant difference.

${ }^{y}$ PRE- $f$ herbicides were applied preemergence on flat ground $30 \mathrm{~d}$ before the beds were formed.

${ }^{x}$ PRE-t herbicides were applied preemergence on the bed top immediately before laying the plastic mulch.

$\mathrm{fb}=$ followed by. 
Table 8 . The effects of herbicide treatments on the strawberry plant biomass and total berry yield at the Gulf Coast Research and Education Center in Balm, FL, in 2018.

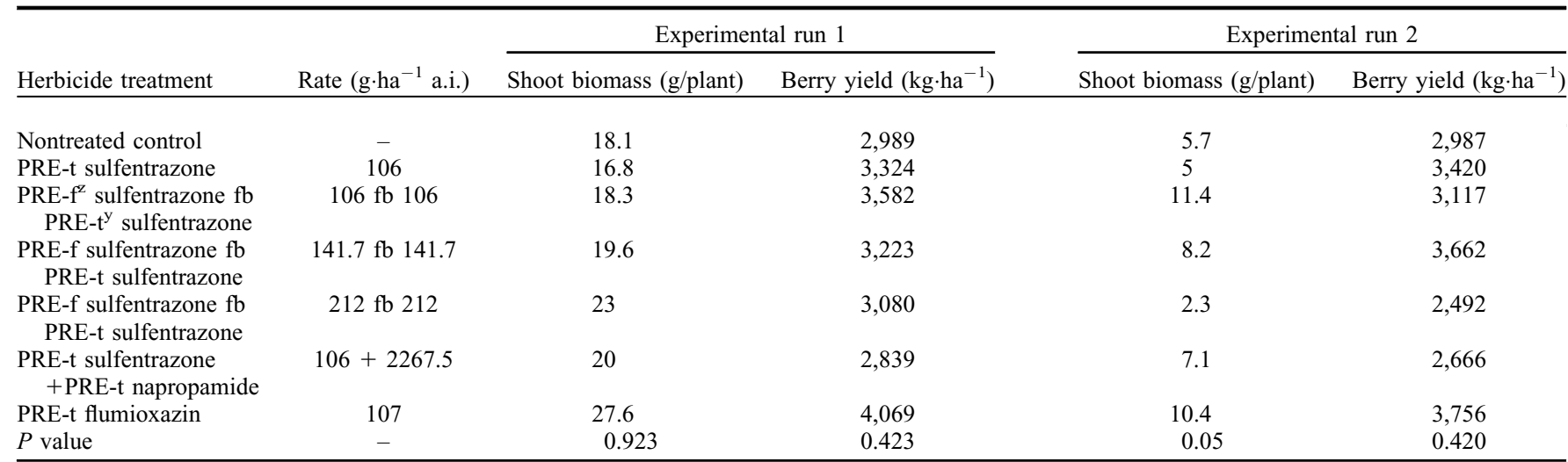

${ }^{\mathrm{z}}$ PRE-f herbicides were applied preemergence on flat ground $30 \mathrm{~d}$ before the beds were formed.

${ }^{y}$ PRE-t herbicides were applied preemergence on the bed top immediately before laying the plastic mulch.

$\mathrm{fb}=$ followed by.

none of the herbicide programs adequately controlled the weeds. Weed control did not improve with increased rates or with the use of PRE-f applications. More research is needed to identify PRE-t and POST herbicide combinations that provide consistent and effective broadleaf, grass, and nutsedge control.

\section{Literature Cited}

Adcock, C.W., W.G. Foshee, G.R. Wehtje, and C.H. Gilliam. 2008. Herbicide combinations in tomato to prevent nutsedge (Cyperus esulentus) punctures in plastic mulch for multi-cropping systems. Weed Technol. 22(1):136-141, https://doi.org/10.1614/WT-07-060.1.

Alsaadawi, I. and N. Salih. 2009. Allelopathic potential of Cyperus rotundus L. I. interference with crops. Allelopathy J. 23(2):297-303.

Bangarwa, S.K., J.K. Norsworthy, and E.E. Gbur. 2009. Cover crop and herbicide combinations for weed control in polyethylene-mulched bell pepper. HortTechnology 19(2):405-410, https:// doi.org/10.21273/HORTSCI.19.2.405.

Boyd, N., R. Kanissery, and P. Dittmar. 2019. Weed management in tomato. HS200. 8 Aug. 2019. $<$ https://edis.ifas.ufl.edu/pdffiles/WG/WG04000. pdf $>$.

Boyd, N. and T. Reed. 2016. Strawberry tolerance to bed-top and drip-applied preemergence herbicides. Weed Technol. 30:492-498.

Boyd, N.S. 2015. Evaluation of preemergence herbicides for purple nutsedge (Cyperus rotundus) control in tomato. Weed Technol. 29(3):480-487, https://doi.org/10.1614/WT-D-14-00133.1.

Daugovish, O. and M.J. Mochizuki. 2010. Barriers prevent emergence of yellow Nutsedge (Cyperus esculentus) in annual plasticulture strawberry (Fragaria $\times$ ananassa). Weed Technol. 24(4):478-482, https://doi.org/10.1614/WT-D10-00012.1.

Figueroa, R., D. Doohan, and J. Cardina. 2005. Efficacy and selectivity of promising herbicides for common groundsel control in newly established strawberry. HortTechnology 15(2):261-266, https:// doi.org/10.21273/HORTTECH.15.2.0261.

Gifford, E.M. and D.E. Bayer. 1995. Developmental anatomy of Cyperus esculentus (Yellow Nutsedge). Int. J. Plant Sci. 156(5):622-629, https://doi.org/10.1086/297284.
Gricher, W.J., B.A. Besler, and K.D. Brewer. 2003. Purple nutsedge control and potato (Solanum tuberosum) tolerance to sulfentrazone and halosulfuron 1. Weed Technol. 17(3):485-490, https://doi.org/10.1614/WT02-045.

Guan, Z., T. Biswas, and F. Wu. 2017. The U.S. tomato industry: An overview of production and trade. University of Florida Extension \# FE1027. 4 pages.

Johnson, W. and B. Mullinix. 2005. Effect of herbicide application method on weed management and crop injury in transplanted cantaloupe production. Weed Technol. 19:108-112.

Miller, M.R. and P.J. Dittmar. 2014. Effect of PRE and POST-directed herbicides for season-long nutsedge (Cyperus spp.) control in bell pepper. Weed Technol. 28(3):518-526, https://doi.org/ 10.1614/WT-D-13-00181.1.

Mohseni-Moghadam, M. and D. Doohan. 2017. Fomesafen crop tolerance and weed control in processing tomato. Weed Technol. 31:441-446.

Morales-Payan, J., B. Santos, W. Stall, and T. Bewick. 1997. Effects of purple nutsedge (Cyperus rotundus) on tomato (Lycopersicon esculentum) and bell pepper (Capsicum annuum) vegetative growth and fruit yield. Weed Technol. 11:672-676.

Morales-Payan, J.P., W.M. Stall, D.G. Shilling, R. Charudattan, J.A. Dusky, and T.A. Bewick. 2003. Above- and belowground interference of purple and yellow nutsedge (Cyperus spp.) with tomato. Weed Sci. 51(2):81-185.

Neeser, C., R. Aguero, and C.J. Swanton. 1997. Survival and dormancy of purple nutsedge (Cyperus rotundus) tubers. Weed Sci. 45:784-790.

Preece, J.E. and P.E. Read. 2005. Mulches, p. 281-291. In: J.E. Preece and P.E. Read (eds.). The Biology of Horticulture: An Introductory Textbook. John Wiley \& Sons, Hoboken, NJ.

Sandea ${ }^{\circledR}$ herbicide. 2015. Yuma, AZ.

Sandhu, R.K., N.S. Boyd, L. Zotarelli, S. Agehara, and N. Peres. 2021. Effect of planting density on the yield and growth of intercropped tomatoes and peppers in Florida. HortScience 56(2):286-290, https://doi.org/ 10.21273/HORTSCI15567-20.

Santos, B.M., J.P. Morales-Payan, W.M. Stall, and T.A. Bewick. 1998. Influence of purple nutsedge (Cyperus rotundus) density and nitrogen rate on radish (Raphanus sativus) yield. Weed Sci. 46(6):661-664. <http://www.jstor.org/stable/ 4045916>.
Shaner, D.L. 2014. Herbicide handbook. Weed Science Society of America, Chambersburg, PA.

Shrefler, J.W., L.P. Brandenberger, C.L. Webber, W. Roberts, M.E. Payton, and L.K. Wells. 2007. POST weed control using halosulfuron in direct-seeded watermelon. Weed Technol. 21(4):851-856, https://doi. org/10.1614/WT-06-175.1.

USDA-NASS. 2020. Vegetables 2019 Summary. U.S. Department of Agriculture. National Agricultural Statistics Service. <https://www.nass. usda.gov/Publications/Todays_Reports/reports/ vegean20.pdf $>$.

Webster, T.M. 2005a. Mulch type affects growth and tuber production of yellow nutsedge (Cyperus esculentus) and purple nutsedge (Cyperus rotundus). Weed Sci. 53(6):834-838, https://doi.org/10.1614/WS-05-029R.1.

Webster, T.M. 2005b. Patch expansion of purple nutsedge (Cyperus rotundus) and yellow nutsedge (Cyperus esculentus) with and without polyethylene mulch. Weed Sci. 53(6):839-845, https://doi.org/10.1614/WS-05-045R.1.

Webster, T.M. 2010. Weed survey-southern states: Vegetable, fruit and nut crops subsection (annual weed survey). Proc. South Weed Sci. Soc. 63:246-257.

Webster, T.M. and T.L. Grey. 2014. Halosulfuron reduced purple nutsedge (Cyperus rotundus) tuber production and viability. Weed Sci. 62(4):637-646, https://doi.org/10.1614/WS-D-1400032.1 .

Yu, J. and N.S. Boyd. 2017. Weed control with and strawberry tolerance to herbicides applied through drip irrigation. Weed Technol. 31:870-876.

Yu, J., N.S. Boyd, and Z. Guan. 2018. Relay-cropping and fallow programs for strawberry-based production system: Effects on crop productivity and weed control. HortScience 53(4):445-450, https://doi.org/10.21273/HORTSCI12658-17.

Yu, J., S.M. Sharpe, and N.S. Boyd. 2019. Fumigants alone or in combination with herbicide for weed management in bell pepper (Capsicum annuит). Crop Prot. 118:31-35, https:// doi.org/10.1016/j.cropro.2018.12.010.

Yu, J., S.S. Sharpe, and N.S. Boyd. 2020. PRE herbicides and POST halosulfuron for purple nutsedge control in tomato grown in plasticulture systems. Weed Technol. 34(5):642-646, https://doi.org/10.1017/wet.2020.24. 